\title{
The Eurasian Dry Grassland Group (EDGG) in 2018-2019
}

\author{
Jürgen Dengler, $2,3, *\left(\mathbb{D}\right.$, Alla Aleksanyan ${ }^{4}(\mathbb{D})$, Didem Ambarl, ${ }^{5,6}$ (D),

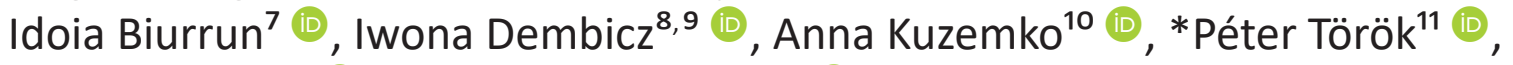 \\ Stephen Venn ${ }^{12}$ (i) \& Michael Vrahnakis ${ }^{13}$ (i)
}

Key words: biodiversity, conservation, Eurasian Dry Grassland Group (EDGG), grassland, Palaearctic Grasslands.

Ključne besede: biotska pestrost, ohranjanje, Evrazijska skupina za suha travišča (EDGG), travišče, palearktična travišča.

Received: 28. 6. 2019

Accepted: 28. 6. 2019

Co-ordinating Editor: Orsolya Valkó

\begin{abstract}
This report summarises the activities and achievements of the Eurasian Dry Grassland Group (EDGG) from January 2018 through July 2019. During the reported period, two Eurasian Grassland Conference (EGCs) took place: the 15th EGC in Sulmona, Italy, and the 16th EGC in Graz, Austria. The $11^{\text {th }}$ and $12^{\text {th }}$ EDGG Field Workshops studied vegetation diversity patterns in the inner alpine valleys of Austria and Switzerland, while the $13^{\text {th }}$ Field Workshop was organised in Armenia. The formerly electronic newsletter of EDGG (Bulletin of the Eurasian Dry Grassland) was transformed into a peer-reviewed international journal, called Palaearctic Grasslands, which now is attracting both scientific and photographic contributions. Furthermore, the EDGG homepage was re-constructed with a new design and content management system. The EDGG has also finalised two grassland-related Special Features during the past 1.5 years in the international journals Tuexenia and Hacquetia, and contributed with eight chapters to the book Grasslands of the World: Diversity, Management and Conservation. The vegetationplot database GrassPlot, containing standardised multi-scale data from Palaearctic grasslands and closely connected with EDGG, has developed well, as did some other regional and national grassland-focused databases.
\end{abstract}
Izvleček
V poročilu predstavljamo aktivnosti in dosežke Skupine za evrazijska suha travišča (EDGG) med januarjem 2018 in julijem 2019. V tem obdobju smo organizirali dve konferenci (EGC): 15. v Sulmoni v Italiji in 16. v Gradcu v Avstriji. Na 11. in 12. EDGG terenski delavnici smo proučevali raznolikost vegetacije notranjih alpskih dolin v Avstriji in Švici, 13. delavnica pa je potekala v Armeniji. Elektronsko glasilo EDGG (Bulletin of the Eurasian Dry Grassland) smo preoblikovali v mednarodno recenzirano revijo Palaearctic Grasslands, kjer bomo objavljali znanstvene in fotografske prispevke. Nadaljnje smo preoblikovali domačo internetno stran EDGG z novim izgledom in sistemom. V zadnjem letu in pol smo uredili dve posebni številki o traviščih v mednarodnih revijah Tuexenia in Hacquetia in prispevali osem poglavij v knjigi Grasslands of the World: Diversity, Management and Conservation. Vegetacijska podatkovna baza GrassPlot, v kateri hranimo standardizirane podatke o palearktičnih traviščih in je neposredno povezana z EDGG se je dobro razvila, kot tudi nekatere druge regionalne in nacionalne podatkovne zbirke povezane $s$ travišči.

1 Vegetation Ecology Group, Institute of Natural Resource Sciences (IUNR), Zurich University of Applied Sciences (ZHAW), Grüentalstr. 14, 8820 Wädenswil, Switzerland.

2 Plant Ecology, Bayreuth Center for Ecology and Environmental Research (BayCEER), University of Bayreuth, Universitätsstr. 30 , 95447 Bayreuth, Germany. E-mail: juergen.dengler@uni-bayreuth.de

3 German Centre for Integrated Biodiversity Research (iDiv) Halle-Jena-Leipzig, DeutscherPlatz 5e, 04103 Leipzig, Germany.

4 Institute of Botany aft. A.L. Takhtajyan NAS RA/ Department of Geobotany and Plant Eco-Physiology 0040, Acharyan 1, Yerevan, Armenia. E-mail: alla.alexanyan@gmail.com 


\section{Introduction}

This report provides an overview of the activities and achievements of the Eurasian Dry Grassland Group (EDGG; http://www.edgg.org) since the previous such report (Venn et al. 2018), that is, from the beginning of 2018 to mid-2019.

\section{About EDGG}

The EDGG is a network of researchers and conservation practitioners interested in natural and semi-natural grasslands of the Palaearctic biogeographic realm. The EDGG was founded in 2008 and currently has 1,299 members from 64 countries (June 2019). Whilst the EDGG has the status of a working group of the International Association of Vegetation Science (IAVS; http://www.iavs.org), it is not restricted to vegetation, but equally deals with flora, fauna, soils, ecosystem services etc. of grasslands. The main activities of the EDGG are (i) the facilitation of international collaboration between researchers, conservationists, site managers, policy and decision-makers; (ii) coordination of scientific and policy-related actions in grassland research, conservation and restoration in the whole Palaearctic; (iii) promotion of the development of databases for grassland classification, best-practices in conservation and restoration; (iv) organisation of annual events, such as the Eurasian Grassland Conferences (EGCs) and Field Workshops; and (v) the dissemination of research findings, news and information in the EDGG Bulletin Palaearctic Grasslands, as well as research papers in Special Features of scientific journals, such as Hacquetia and Tuexenia.

Further information about the EDGG can be found from our website http://www.edgg.org/ and Facebook group https://www.facebook.com/groups/938367279561202/. Membership of the EDGG is free of charge and open to anyone interested in Palaearctic grasslands. If you would like to become a member, then simply send an e-mail to our Membership Administrator, Idoia Biurrun (idoia.biurrun@ehu.es).

The biennial election of our governing body, the Executive Committee (EC), in spring 2019 saw the departure of Mike Vrahnakis, who decided not to stand for re-election, and the election of two new members, Alla Aleksanyan and Iwona Dembicz. Eleven candidates stood in the EC elections, of which eight were duly elected for the term 2019-2021. The chairs in the current executive committee are Alla Aleksanyan (Armenia), Didem Ambarlı (Germany/Turkey), Idoia Biurrun (Spain), Iwona Dembicz (Poland), Jürgen Dengler (Switzerland), Anna Kuzemko (Ukraine), Péter Török (Hungary), and Stephen Venn (Finland). The distribution of responsibilities of the old (2017-2019) and current (2019-2021) Executive Committee is shown in Table 1.

Table 1: Distribution of responsibilities in the old (2017-2019) and current (2019-2021) Executive Committee. Abbreviations for responsible persons and (deputy/deputies) are as follows: $\mathrm{AA}=$ Alla Aleksanyan, $\mathrm{DA}=$ Didem Ambarlı, IB=Idoia Biurrun, ID= Iwona Dembicz, JD = Jürgen Dengler, AK=Anna Kuzemko, MV=Michael Vrahnakis, PT=Péter Török, and SV=Stephen Venn.

Tabela 1: Zadolžitve v starem (2017-2019) in trenutnem (2019-2021) izvršnem odboru. Okrajšave imen odgovornih oseb in namestnikov: $\mathrm{AA}=$ Alla Aleksanyan, $\mathrm{DA}=$ Didem Ambarlı, IB=Idoia Biurrun, ID=Iwona Dembicz, JD=Jürgen Dengler, AK=Anna Kuzemko, MV=Michael Vrahnakis, PT = Péter Török in SV=Stephen Venn.

\begin{tabular}{lll}
\hline Responsibility & EC 2017-2019 & EC 2019-2021 \\
Membership administrator & IB & IB \\
Secretary-General & SV (PT) & JD (PT) \\
Eurasian Grassland Conference & MV (DA) & DA (AA, SV) \\
Field Workshops & JD (IB) & ID (IB) \\
Palaearctic Grasslands & AK (IB, JD) & AK (IB, JD) \\
Special features & JD (PT) & JD (PT) \\
Treasurer & PT & PT \\
Contact to IAVS & PT (IB) & PT (IB) \\
Facebook & AK (SV) & SV (AK) \\
Website & DA & AA (DA) \\
\hline
\end{tabular}

5 Terrestrial Ecology Research Group, Department for Ecology and Ecosystem Management, Technical University of Munich, Hans-Carl-von-Carlowitz-Platz 2, D-85354 Freising, Germany. E-mail: didem.ambarli@gmail.com

6 Department of Agricultural Biotechnology, Faculty of Agricultural and Natural Sciences, Düzce University, 81620 Düzce, Turkey.

7 Department of Plant Biology and Ecology, Faculty of Science and Technology, University of the Basque Country UPV/EHU, P. O. Box 644, 48080 Bilbao, Spain.

8 Botanical Garden Center for Biological Diversity Conservation in Powsin, Polish Academy of Sciences, Prawdziwka St. 2, 02-973 Warsaw, Poland.

9 Department of Plant Ecology and Environmental Conservation, Faculty of Biology, University of Warsaw, Żwirki i Wigury St. 101, 02-089 Warsaw, Poland. E-mail: i.dembicz@gmail.com

10 M.G. Kholodny Institute of Botany, National Academy of Sciences of Ukraine. E-mail: anyameadow.ak@gmail.com

11 MTA-DE Lendület Functional and Restoration Ecology Research Group, Debrecen, Egyetem sqr 1, 4032 Hungary. E-mail: molinia@gmail.com

12 Ecosystems and Environment Research Programme, Faculty of Biological and Environmental Sciences, University of Helsinki, P. O. Box 65 (Viikinkaari 11), 00014, Finland. E-mail: stephen.venn@helsinki.fi

13 Department of Forestry, Wood and Design Sciences, University of Thessaly, GR-43100, Karditsa, Greece. E-mail: mvrahnak@teilar.gr

* Corresponding author: Péter Török, molinia@gmail.com 
The EDGG homepage (https://edgg.org/) was re-constructed on a new server and with a new content management system, easy-to-follow layout and many other innovations. The new homepage contains all information about the EDGG family: past, current and planned conferences (https://edgg.org/egc/overview) and field workshops (https://edgg.org/fw/overview), as well as publications (https://edgg.org/publ/overview): EDGG journal, special features and publications from members. Furthermore, the Events and News sections inform visitors about upcoming events of interests and other news. A login system allows participants of previous events to register for future ones without having to repeatedly enter their personal data.

\section{Events of EDGG in 2018-2019}

One of the core activities of EDGG is its annual conferences. While they started in 2004, as meetings of the German Arbeitsgruppe Trockenrasen, it was in 2009 that they were re-named as European Dry Grassland Meetings and organised by the EDGG. Since 2016 the name changed again to its current form: Eurasian Grassland Conferences - EGCs. This year we have the pleasure of celebrating the $10^{\text {th }}$ anniversary of EDGG organised conferences. The EGC is a well-established fixture between members of the EDGG and year by year it is becoming better known amongst plant ecologists, botanists and phytosociologists (Vrahnakis 2019).

The $15^{\text {th }}$ EGC took place in Sulmona, Italy, in June 2018, with the theme of cooperating for grassland conservation (Burrascano et al. 2018; Figure 1a). It was organised jointly by the University of Rome La Sapienza and the Majella National Park and our hosts were Sabina Burrascano, Giampiero Ciaschetti, Eleonora Giarrizzo, Emanuela Carli, Eva Del Vico and Laura Facioni. Participants joined four oral presentation sessions, a poster session, two workshops on preparing proposals for LIFE+ and INTERREG and Natura 2000 Biogeographical Process and keynote talks by Pietro Brandmayr, and Jürgen Dengler, as well as mid and post-conference excursions to a variety of semi-natural grasslands in the region. The conference provided an opportunity to see the best examples of the species-rich secondary pastures of Majella National Park, with some evidence of deterioration in overgrazed sites. The subsequent $16^{\text {th }} \mathrm{EGC}$ was jointly organized in Austria and Slovenia during May-June

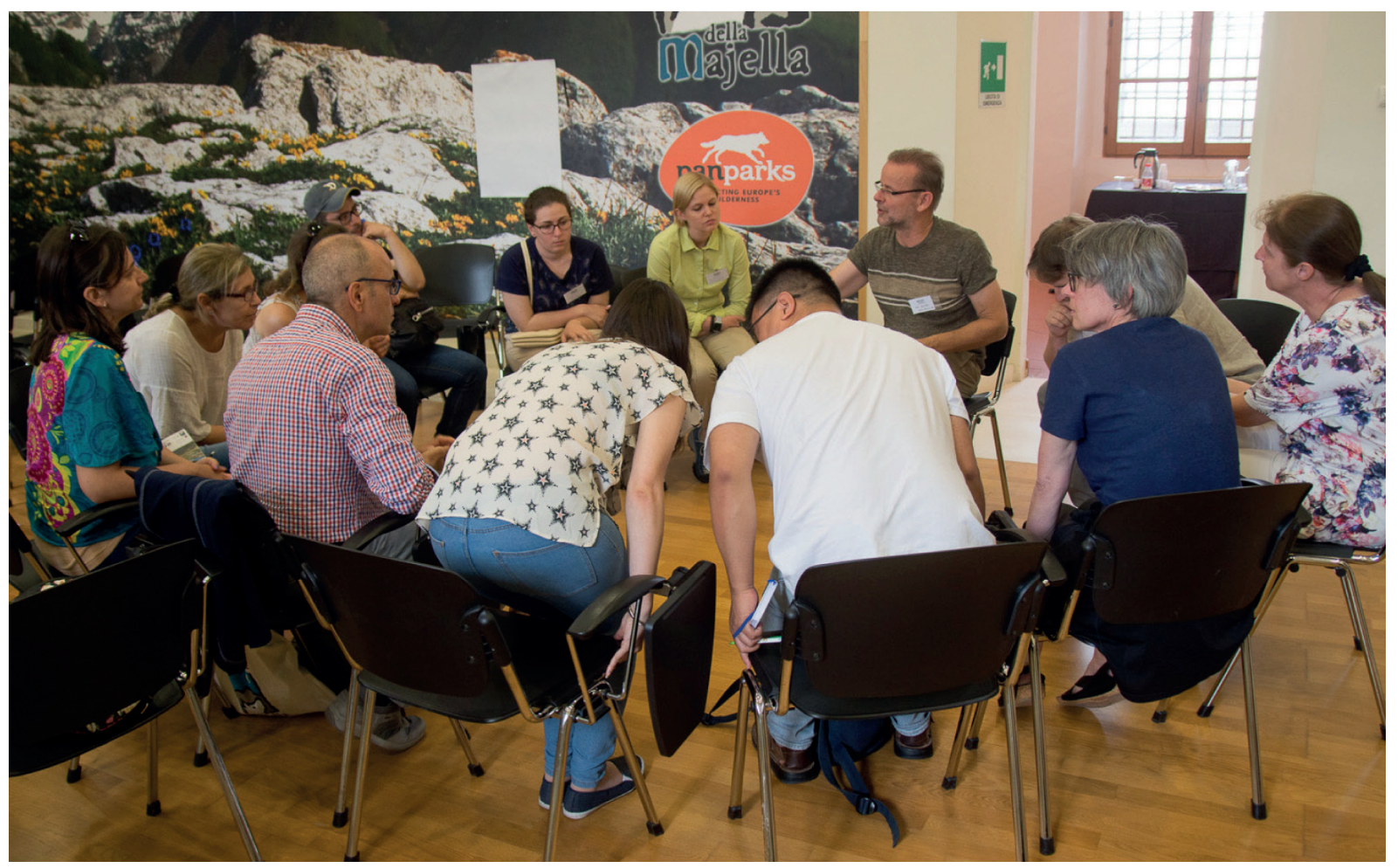

Figure 1a: Impressions from the $15^{\text {th }}$ Eurasian Grassland Conference in Sulmona, Italy (Photo by J. Dengler).

Slika 1a: Vtisi z 15. Evrazijske konference o traviščih v Sulmoni v Italiji (Foto J. Dengler). 
2019, on the topic of the economic value of species-rich grasslands in the Palaearctic realm (Figure 1b). It provided an opportunity to attend workshops on scientific writing, Natura 2000 Biogeographical Process, and take part in a field excursion on bryophyte identification, led by Christian Berg. The conference had three keynote talks, by Zsolt Molnár, Matej Vidrih and Wolfgang Willner, as well as a mid-conference excursion to a variety of relevant habitats in Neumarkt/Steiermark (Austria). The post-conference tour took us to semi-natural grasslands in Slovenia, with destinations of the Goričko Landscape Park, the Haloze region and the Slovenian Dinaric region. The event was hosted by the University of Graz (Austria), and University of Maribor (Slovenia) and our hosts were Martin Magnes, Nataša Pipenbaher, and Sonja Škornik. The $17^{\text {th }}$ Eurasian Grassland Conference will be held during 2020, in Bilbao, Spain, organized by Idoia Biurrun.

The EDGG Field Workshops (Dengler 2009, Dengler et al. 2009) are the second major regular EDGG organised events that increasingly attracts grassland specialists of many countries and of any academic level (Vrahnakis et al. 2013, Dengler et al. 2016). The main aim of Field Workshops is to sample Palaearctic grasslands across mul- tiple scales (0.0001-100 $\mathrm{m}^{2}$ ) and taxa (vascular plants, bryophytes and lichens) and to generate standardised high-quality biodiversity data, supplemented by local environmental data.

The $11^{\text {th }}$ EDGG Field Workshop was held in the Eastern Alps, Austria from $6^{\text {th }}$ to $13^{\text {th }}$ July 2018, with Martin Magnes, Philipp Kirschner and Helmut Mayrhofer as the local organizers (Magnes et al. 2018; Figure 1c). The field workshop was attended by 18 participants from 10 countries and 15 nested-plot series and 37 additional normal plots were sampled. The $12^{\text {th }}$ Field Workshop also targeted the inner-alpine valleys but in Switzerland, organised by Jürgen Dengler and his co-workers (11-19 May, 2019; Dengler et al. 2019, Figure 1d). This field workshop was attended by 16 participants from 5 countries. During the field workshop, 30 nested-plot series and 81 additional normal plots were sampled. The $13^{\text {th }}$ Field Workshop: "Grasslands of Armenia along an elevational gradient" was held between 26 June -7 July 2019 in Armenia, organised by Alla Aleksanyan. Further details will be included in the next report, as this field workshop was still in progress at the time of the submission of this manuscript.

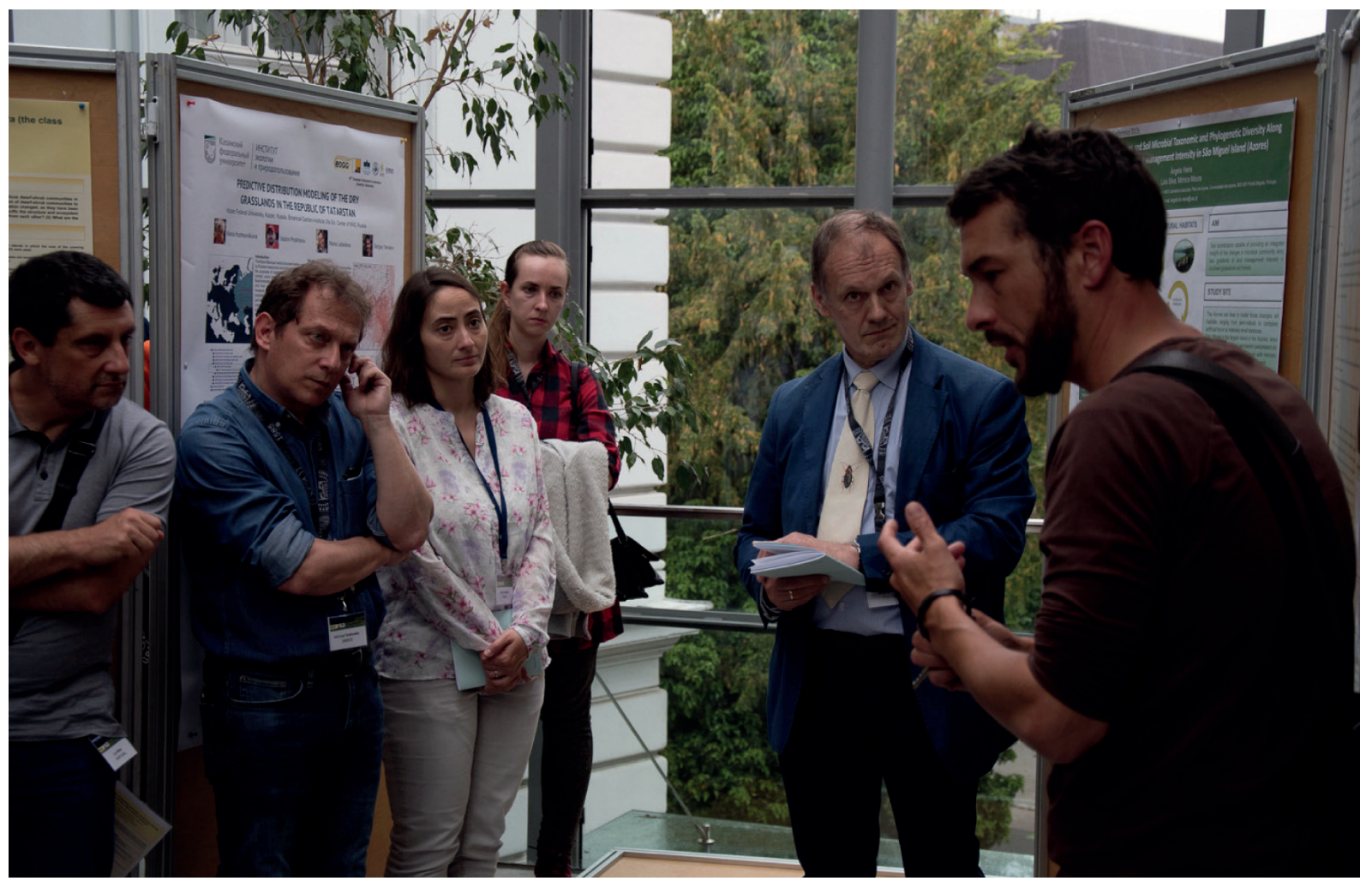

Figure $1 \mathrm{~b}$ : Impressions from $16^{\text {th }}$ Eurasian Grassland Conference in Graz, Austria (Photo by J. Dengler).

Slika 1b: Vtisi z 16. Evrazijske konference o traviščih v Gradcu v Avstriji (Foto J. Dengler). 
Figure 1c: Impressions from $11^{\text {th }}$ EDGG Field Workshop in the Eastern Alps, Austria (Photo by J. Dengler).

Slika 1c: Vtisi z 11. EDGG terenske delavnice v vzhodnih Alpah v Avstriji (Foto J. Dengler).
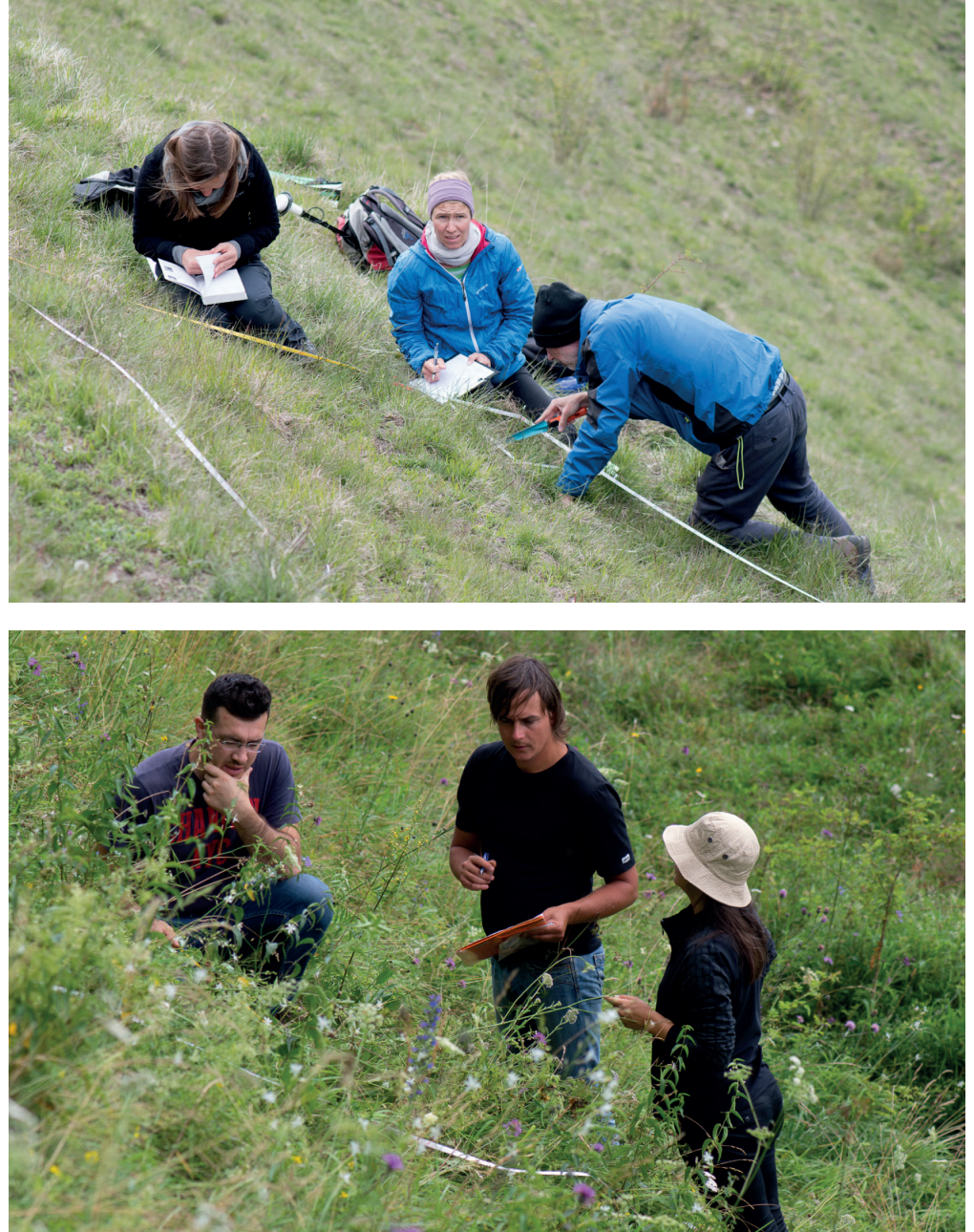

Figure 1d: Impressions from $12^{\text {th }}$ Field workshop in the inner-alpine valleys, Switzerland (Photo by J. Dengler).

Slika 1d: Vtisi z 12. EDGG terenske delavnice v notranjih alpskih dolinah v Švici (Foto J. Dengler).

\section{Publications of EDGG in 2018-2019}

During 2018, the former Bulletin of the Eurasian Dry Grassland Group has been transformed into a fully-fledged scientific journal of a new type, called Palaearctic Grasslands (PG). Currently six issues of PG have been published. While PG continues to be the platform for official announcements of the EDGG Executive Committee to the members ("News", "EDGG Events"), for "Short Contributions" from members for members, "Book Reviews", overviews of "Recent Publications of our Members" related to grasslands and "Forthcoming Events", it now has two major new elements: (i) PG now publishes scientific articles in four categories: "Research Article", "Review", "Forum Article" and "Scientific Report". They are subject to editorial peer review, which ensures on the one hand scientific soundness, and on the other hand fast decisions. (ii) PG has a strong focus on excellent quality photography from Palaearctic grasslands, their flora and fauna and the people using them. The new format of "Photo Stories" allows the submission of grassland articles of a couple of pages, consisting mainly of photos with brief texts, which celebrate the beauty of certain grasslands of some region and their rich biota.

Moreover, we now have a regular "Photo Competition" on selected topics, such as animal-plant interactions or grassland people, of which the three best contributions are presented in the subsequent issue. PG is made possible by an international Editorial Board of 30 dedicated members from 17 countries throughout the Palaearctic, from Spain to Japan.

EDGG organised three special issues during the reported period. There were two regular issues organised in the journals Hacquetia and Tuexenia. In Hacquetia, 
the fourth Special Feature was edited by Orsolya Valkó, Stephen Venn, Idoia Biurrun, Rocco Labadessa, Jacqueline Loos and Michal Zmihorski. This special feature was initiated by members of the EDGG attending the 13th Eurasian Grassland Conference (EGC) at Sighisoara, Romania, in September 2016. It contains six papers dealing with the conservation, ecology, syntaxonomy and zoology of grassland and steppe habitats from East Europe to central Asia. The core topic of the issue is the challenge of abandonment in the conservation of Palaearctic grasslands (Valkó et al. 2018). The 13th regular EDGG Special Feature in Tuexenia focuses on the conservation, management, restoration and biodiversity of semi-natural and natural grasslands in Central-Europe. The special feature was guest edited by Balázs Deák, Thomas Becker, Steffen Boch and Viktoria Wagner (Deák et al. 2018). Altogether 43 authors from six countries contributed to this publication. A further special issue organised by EDGG was guest edited by Péter Török, Barbara Neuffer, Karl-Georg Bernhardt and Karsten Wesche in the journal Flora. This special issue is devoted to the ecology and evolution of steppe biodiversity and forms a nice addition to the formerly published issues and papers on the topic (Török et al. 2016, Wesche et al. 2016). So far 20 papers have been invited and the tentative publication deadline is in the first months of 2020. During the reported period, EDGG members worked on a comprehensive book Grasslands of the World: Diversity, Management and Conservation for the publisher CRC (Squires et al. 2018). The book was co-edited by EDGG chair Jürgen Dengler, and a team of 28 EDGG members wrote eight regional chapters (nearly half of the book) on Western and Northern Europe (Dengler \& Tischew 2018), Eastern Europe (Török et al. 2018), Mediterranean Basin and the Middle East (Ambarli et al. 2018), Russia (Reinecke et al. 2018), Kazakhstan and Middle Asia (Bragina et al. 2018), China and Mongolia (Pfeiffer et al. 2018), and Japan (Ushimaru et al. 2018). All of these chapters were introduced by a synthesis chapter by Török \& Dengler (2018). In these chapters, they summarised the origin, biodiversity, types, threats, management, and conservation issues of grasslands for the first time for the whole Palaearctic.

\section{Vegetation-plot databases associated with EDGG}

In our last report (Venn et al. 2018), we informed about the re-launch of the EDGG managed GrassPlot database, based on the former Database Species-Area Relationships in Palaearctic Grasslands (Dengler et al.
2012). GrassPlot stores multi-scale richness, composition and environmental data from precisely delimited plots of grasslands and other open habitats of the Palaearctic Realm. Since its formal establishment during an international workshop in March 2017 (Janišová et al. 2017), with 87 datasets, 27,355 plots and 1,144 nestedplot series of at least four grain sizes, the database has increased its content and spatial coverage. Dengler et al. (2018) reported on the first publicly released GrassPlot version 1.00 (January 2018). This version already contained 168,997 plots and 2,797 nested-plot series from 126 contributing datasets. Since the publication of that report, the database has continued to expand, and a new report will be published shortly in Palaearctic Grasslands, providing an update on the content and functionality of GrassPlot version 2.0. This new version contains 190,684 plots and 4,654 nested-plot series from 184 datasets (Figure 2).

A new Governing Board of GrassPlot was elected in February 2019. Jürgen Dengler, Idoia Biurrun, Iwona Dembicz and Riccardo Guarino continue from the former Governing Board, and Jutta Kapfer, Sabina Burrascano and Remigiusz Pielech are new members for the period 2019-2021.

In addition to GrassPlot, the development of some national databases was also been facilitated by EDGG. The Ukrainian Grassland Database contains 11,953 relevés (June, 2019). During 2018-2019, work has been done to improve and refine the data in the database. Some gaps in the representativeness of the data were filled - several thousands of relevés from the Western regions of Ukraine (Chernivtsi and Ivano-Frankivsk regions) and the Steppe Zone (Odessa, Mykolaiv and Kherson regions) were added. Also, the Romanian Grassland Database (RGD) and the Balkan Dry Grassland Database (BDGD) have developed very dynamically under the leadership of Kiril Vassilev, while the Nordic-Baltic Grassland Vegetation Database (NBGVD) and the German grassland database (GrassVeg.DE) received few additions. All five regularly contribute valuable data to continental and global analyses, organised via the European Vegetation Archive (EVA) and sPlot, respectively.

\section{Acknowledgements}

The Executive Committee of the EDGG is thankful to our mother organisation IAVS for their ongoing financial support. We are also thankful to EDGG members for their charitable donations and personal contributions to support our activities 


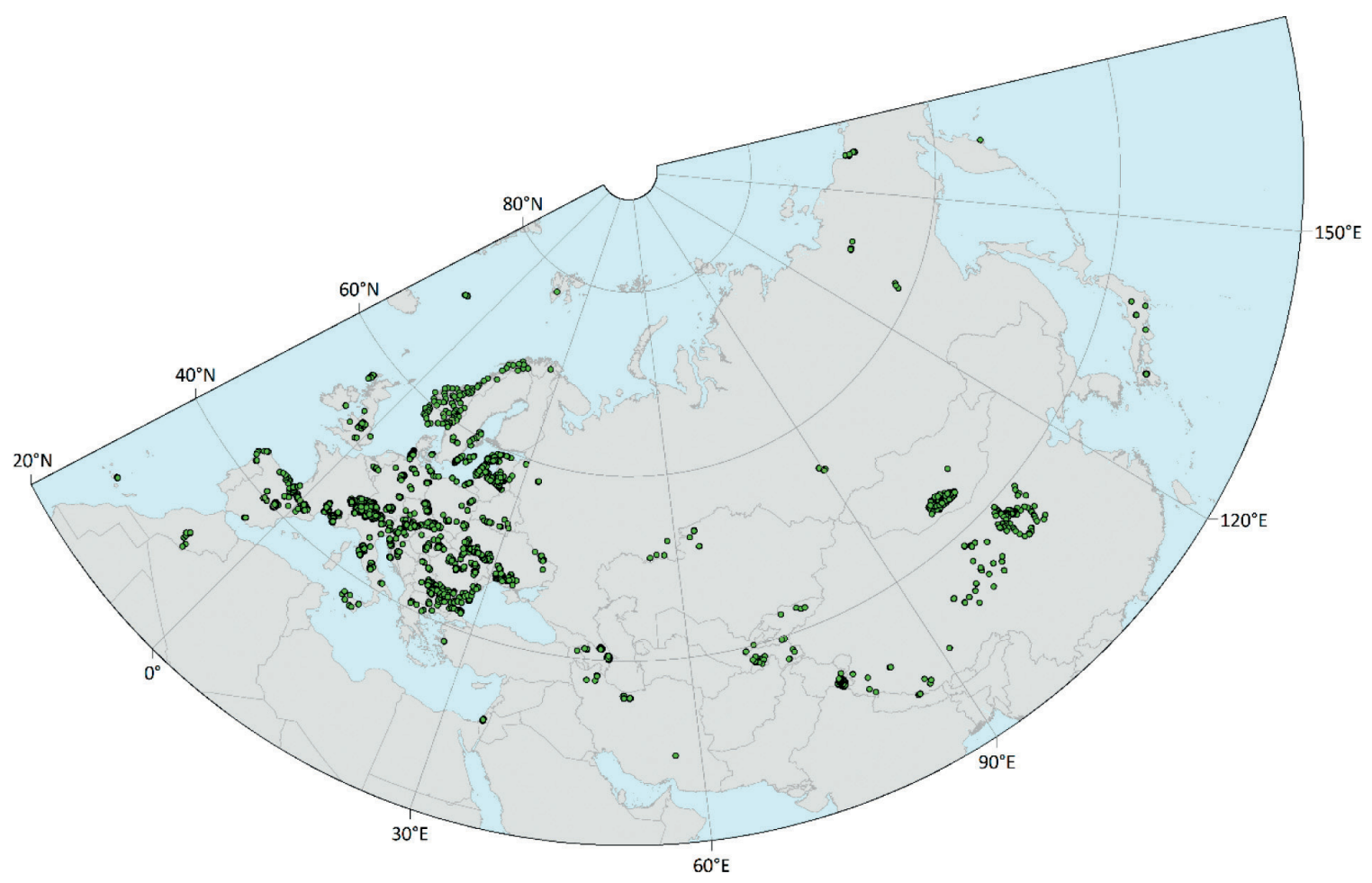

Figure 2: Map showing the spatial distribution of the plots contained in GrassPlot v. 2.0.

Slika 2: Zemljevid razširjenosti ploskev shranjenih v GrassPlot v. 2.0.

Jürgen Dengler: https://orcid.org/0000-0003-3221-660X

Alla Aleksanyan: https://orcid.org/0000-0003-4073-1812

Didem Ambarlı: https://orcid.org/0000-0001-5589-9373

Idoia Biurrun: https://orcid.org/0000-0002-1454-0433

Iwona Dembicz: https://orcid.org/0000-0002-6162-1519

Anna Kuzemko: https://orcid.org/0000-0002-9425-2756

Péter Török: https://orcid.org/0000-0002-4428-3327

Stephen Venn: https://orcid.org/0000-0002-0318-6256

Michael Vrahnakis: https://orcid.org/0000-0001-9079-3697

\section{References}

Ambarl1, D., Vrahnakis, M., Burrascano, S., Naqinezhad, A., \& Pulido Fernández, M. 2018: Grasslands of the Mediterranean Basin and the Middle East and their management. In: Squires, V.R., Dengler, J., Feng, H. \& Hua, L. [ed.]: Grasslands of the World: Diversity, Management and Conservation. pp. 89-112, CRC Press: Boca Raton.

Bragina, T.M., Nowak, A., Vanselow, K.A. \& Wagner, V. 2018: Grasslands of Kazakhstan and Middle Asia: The ecology, conservation and use of a vast and globally important area. In: Squires, V.R., Dengler, J., Feng, H. \& Hua, L. [ed.]: Grasslands of the World: Diversity, Management and Conservation. pp. 141-169, CRC Press: Boca Raton.

Burrascano, S., Ciaschetti, G., Vrahnakis, M. \& Dengler, J. 2018: Report on the 15th Eurasian Grassland Conference in Sulmona, Italy. Palaearctic Grasslands 38: 12-17.
Deák, B., Becker, T., Boch, S. \& Wagner, V. 2018: Conservation, management and restoration of semi-natural and natural grasslands in Central Europe - Editorial to the 13th EDGG Special Feature. Tuexenia 38: 305-310.

Dengler, J. 2009. A flexible multi-scale approach for standardised recording of plant species richness patterns. Ecological Indicators 9: $1169-1178$.

Dengler, J., Ruprecht, E., Szabó, A., Turtureanu, D., Beldean, M.,Ugurlu, E., Pedashenko, H., Dolnik, C. \& Jones, A. 2009. EDGG cooperation on syntaxonomy and biodiversity of Festuco-Brometea communities in Transylvania (Romania): report and preliminary results. Bulletin of the European Dry Grassland Group 4: 13-19.

Dengler, J., Todorova, S., Becker, T., Boch, S., Chytrý, M., Diekmann, M., Dolnik, C., Dupré, C., Giusso del Galdo, G.P., (...) \& Vassilev, K. 2012: Database Species-Area Relationships in Palaearctic Grasslands. Biodiversity \& Ecology 4: 321-322.

Dengler, J., Biurrun, I., Apostolova, I., Baumann, E., Becker, T., Berastegi, A., Boch, S., Dembicz, I., Dolnik, C., (...) \& Weiser, F. 2016: Scale-dependent plant diversity in Palaearctic grasslands: a comparative overview. Bulletin of the Eurasian Dry Grassland Group 31: $12-26$

Dengler, J. \& Tischew, S. 2018: Grasslands of Western and Northern Europe-Between intensification and abandonment. In: Squires, V.R., Dengler, J., Feng, H. \& Hua, L. [ed.]: Grasslands of the World: Diversity, Management and Conservation. pp. 27-63, CRC Press: Boca Raton. 
Dengler, J., Wagner, V., Dembicz, I., García-Mijangos, I., Naqinezhad, A., Boch, S., Chiarucci, A., Conradi, T., Filibeck, G., (...) \& Biurrun, I. 2018: GrassPlot - a database of multi-scale plant diversity in Palaearctic grasslands. Phytocoenologia 48: 331-347.

Dengler, J., Gehler, J., Aleksanyan, A., Fayvush, G. \& Biurrun, I. 2019: EDGG Field Workshops 2019 - the international research expeditions to study grassland diversity across multiple scales and taxa: Call for participation. Palaearctic Grasslands 41: 9-22

Janišová, M., Dengler, J. \& Biurrun, I. 2017: GrassPlot - The new database of multi-scale plant diversity of Palaearctic grasslands. IAVS Bulletin 2017(2): 18-22.

Magnes, M., Mayrhofer, H., Kirschner, P., Stöhr, O., Schwager, P., Dengler, J. \& Biurrun, I. 2018: Invitation and guide to the $11^{\text {th }}$ EDGG Field Workshop. Grasslands of inneralpine dry valleys: part 1, Eastern Alps. Austria, 6-13 July 2018. Bulletin of the Eurasian Dry Grassland Group 36: 12-25.

Pfeiffer, M., Dulamsuren, C., Jäschke, Y. \& Wesche, K. 2018 Grasslands of China and Mongolia: Spatial extent, land use and conservation. In: Squires, V.R., Dengler, J., Feng, H. \& Hua, L. [ed.]: Grasslands of the World: Diversity, Management and Conservation. pp. 170-198, CRC Press: Boca Raton.

Reinecke, J.S.F., Smelansky, I.E., Troeva, E.I., Trofimov, I.A. \& Trofimova, L.S. 2018: Land use of natural and secondary grasslands in Russia. In: Squires, V.R., Dengler, J., Feng, H. \& Hua, L. [ed.]: Grasslands of the World: Diversity, Management and Conservation. pp. 113-138, CRC Press: Boca Raton.

Squires, V.R., Dengler, J., Feng, H. \& Hua, L. 2018: Grasslands of the World: Diversity, Management and Conservation. CRC Press, Boca Raton, pp. 412.

Török, P. \& Dengler, J. 2018: Palaearctic Grasslands in Transition: Overarching Patterns and Future Prospects. In: Squires, V.R., Dengler, J., Feng, H. \& Hua, L. (eds.): Grasslands of the World: Diversity, Management and Conservation, CRC Press: Boca Raton, pp. 15-25.
Török, P., Janišová, M., Kuzemko, A., Rūsina, S. \& Dajić Stevanović, Z. 2018: Grasslands, their threats and management in Eastern Europe. In: Squires, V.R., Dengler, J., Feng, H. \& Hua, L. [ed.]: Grasslands of the World: Diversity, Management and Conservation. pp. 64-88, CRC Press: Boca Raton.

Török, P., Wesche, K., Ambarli, D., Kamp, J. \& Dengler, J. 2016: Step(pe) up! Raising the profile of the Palaearctic natural grasslands. Biodiversity \& Conservation 25: 2187-2195.

Ushimaru, A., Uchida, K. \& Suka, T. 2018: Grassland biodiversity in Japan: threats, management and conservation. In: Squires, V.R., Dengler, J., Feng, H. \& Hua, L. [ed.]: Grasslands of the World: Diversity, Management and Conservation. pp. 197-218, CRC Press: Boca Raton.

Valkó, O., Venn, S., Żmihorski, M., Biurrun, I., Labadessa, R. \& Loos, J. 2018. The challenge of abandonment for the sustainable management of Palaearctic natural and semi-natural grasslands. Hacquetia 17: 5-16.

Venn, S., Ambarlı, D., Biurrun, I., Dengler, J., Kuzemko, A., Török, P. \& Vrahnakis, M. 2018: The Eurasian Dry Grassland Group (EDGG) in 2016-2017. Hacquetia 17(1): 17-23.

Vrahnakis, M.S., Janišová, M., Rūsina, S., Török, P., Venn, S. \& Dengler, J. 2013: The European Dry Grassland Group (EDGG): stewarding Europe's most diverse habitat type. In: Baumbach, H. \& Pfützenreuter, S. (eds.): Steppenlebensräume Europas - Gefährdung, Erhaltungsmaßnahmen und Schutz. Thüringer Ministerium für Landwirtschaft, Forsten, Umwelt und Naturschutz (Publisher), Erfurt, pp. 1-16.

Vrahnakis, M. 2019: Ten years of Eurasian Grassland Conferences: a vehicle for the future of the EDGG. Palaearctic Grasslands 42: 8-15.

Wesche, K., Ambarli, D., Kamp, J., Török, P., Treiber, J. \& Dengler, J. 2016: The Palaearctic steppe biome: a new synthesis. Biodiversity \& Conservation 25: 2197-2231. 